\title{
Determining the Effect of Banking Service Quality on Customer Loyalty Using Customer Satisfaction as a Mediating Variable: An Applied Study on the Jordanian Commercial Banking Sector
}

\author{
Zaher Abdel Fattah Al-Slehat ${ }^{1}$ \\ ${ }^{1}$ Associate Professor, Department of Business Economic, Business Faculty, Tafila Technical University, Tafila, \\ Jordan \\ Correspondence: Zaher Abdel Fattah Al-Slehat, Department of Business Economic, Tafila Technical University, \\ P.O Box 179, 66110, Tafila, Jordan.
}

Received: February 16, 2021

Accepted: March 8, $2021 \quad$ Online Published: March 19, 2021

doi:10.5539/ibr.v14n4p58

URL: https://doi.org/10.5539/ibr.v14n4p58

\begin{abstract}
Banks operate in an environment characterized by competition between banking service providers and the continuous development of financial technology. On this basis, the quality of banking services determines the success of banks. This study aims to test customer satisfaction as a mediating variable in the relationship between banking service quality and customer loyalty using the convenience sample method. Using the SmartPLS software, the data analysis and hypothesis test results show that the quality of banking service in all its dimensions positively affects customer loyalty. Moreover, customer satisfaction mediates such a relationship. Accordingly, the Jordanian commercial banking sector should focus on the tangibility dimension and influence customer satisfaction to promote customer loyalty.
\end{abstract}

Keywords: banking service quality, customer satisfaction, customer loyalty, financial sector

\section{Introduction}

The Jordanian financial sector is characterized by competitiveness. The financial sector Consists of various institutions. Where it includes the central bank, thirteen commercial banks, seven foreign commercial banks, three Jordanian Islamic banks, and a foreign Islamic bank, in addition to specialized credit institutions, exchange companies, and representative offices. The banking sector indicators recorded growth at the end of 2019 in various fields. Assets increased by $5.4 \%$, and credit facilities and deposits grew by $3.7 \%$ and $4.3 \%$, respectively (Central Bank of Jordan \& Association of banks in Jordan, 2019). This statistics indicates that the banking sector enjoys a large market share in terms of assets, facilities and deposits, which requires continuous improvement and development in banking services to gain a competitive advantage reflected in customer satisfaction and loyalty.

Clients have a significant role in the success of the banking business. Hence, the banking departments should provide banking services characterized by innovation and diversification. These services should be in line with the desires of customers or even exceed their expectations. Ultimately, they should increase customer satisfaction and guarantee their loyalty. This study highlights a pressing topic in the banking industry.

\section{Theoretical Framework}

\subsection{Banking Service Quality}

Kumar et al., (2010) indicated that the banking environment has become dynamic and competitive due to globalization. Banks should focus on improving their service quality to maintain customers and increase revenues and market shares. Alic et al. (2017) indicated that service quality is a three-level concept, including interaction quality, physical environment quality and result quality.

The quality of banking service refers to customers' general impression of the superiority of the institution and its services. On this basis, it should be par with their expectations and needs, as it is a significant tool for measuring customer satisfaction (Bitner \& Hubbert, 1994; Edvardsson et al., 1994; Kadir et al., 2011). Researchers (e.g. Brown et al., 1993; Carman, 1990) used the SERVPERF model to measure service quality in the banking sector. However, its reliability remains questionable. As an alternative, the SERVQUAL model becomes one of the most used methods in measuring service quality in the banking sector. Many studies (e.g. Phan \& Nham, 2015; Angur et 
al., 1999; Lau et al., 2013) have proven its applicability and efficiency.

Parasuraman et al. (1988) proposed an innovative tool to measure consumers' perception of service quality that later became known as service quality. Service quality includes all or some of the following dimensions: consumer reliability, responsiveness, tact and appreciation, communication, trust, communication, credibility, safety, knowledge of customer and tangibility.

To achieve the research objectives, the researcher uses the following dimensions of banking service quality: tangibility, reliability, responsiveness, sympathy and safety.

Prior studies (e.g. Ajmal et al., 2018; Naeem et al., 2009; Lomendra et al., 2019; Zeithaml et al., 2002; Raza et al., 2020; Kotler \& Keller, 2012; Fragoso \& Espinoza, 2017; Parasuraman et al., 1988; Eltahir \& Abdallah, 2019; Al Karim \& Chowdhury, 2014) used the following dimensions of banking service quality:

Tangibility: It includes physical evidence of a service, such as physical facilities, machinery, equipment and personnel.

Reliability: It indicates that the organization can provide the promised service reliably and accurately.

Responsiveness: It concerns the willingness of employees to provide assistance and service to clients.

Empathy: It refers to the individual care and attention given to clients.

Safety: It indicates customers' confidence and trust in dealing with banks, and the service is free from risks or errors.

\subsection{Customer Satisfaction}

The banking sector seeks to provide the best services to its customers. Customer satisfaction determines the success of any organization. So banks should identify their customers' needs and the time and resources required for these services (Kadir et al., 2011). Customer satisfaction refers to the results obtained from the actual evaluation between the requirements and the outcomes. (Sakhaei et al., 2014).

Liu et al. (2008) defined the following criteria to measure the level of customer satisfaction to obtain services:

Satisfaction: It is a perception that clients develop by accepting goods or services.

Content: It refers to the advantages of goods and services and the benefits of experimenting with consuming a good or service.

Relived: The services provided reduce the negative feeling of clients.

Novelty: The ability of goods and services to excite customers (or gain their attention).

Surprise: The surprise and unexpected pleasure that the service brings to customers.

\subsection{Customer Loyalty}

Customer loyalty refers to their repurchase intention (Flint et al., 2011; Fida et al., 2020). It is also known as buyback behavior, representing customer experience in using the service. Customer loyalty is considered a result of customer satisfaction. A customer who has good experience with a company will continue his subscription for its services. This action makes him sincere and rational in making the purchase decision for the service. Empirical evidence shows that organizations that care about their customers' expectations can achieve customer loyalty.

Kotler (2003); Kotler and Keller (2006) defined loyalty as a measure of customers' willingness to participate in the activities of an organization. Loyalty is built with customers by constantly contacting them through various means (e.g. E-mail, thank you letters, good treatment of employees, showing interest in an organization and supporting their success and happiness).

Khan and Fasih (2014) also explained that customer loyalty involves customers' psychological process, bias and decision-making and has a relation to some brands, final purchase and post-purchase behaviour.

\section{Research Problem}

The increasing competition and tremendous developments in banking service technology have imposed increasing difficulties, such as avoiding stereotypes and repetitive banking services. To achieve excellence in the quality of banking service, banks should address their shortcomings and improve their strength to gain customer loyalty. In turn, customer loyalty will increase bank profits. Accordingly, this study answers the following questions:

1. Does the quality of banking service affect customer loyalty? 
2. Does the quality of banking service affect customer satisfaction?

3. Does customer satisfaction affect customer loyalty?

4. Does customer satisfaction mediate the relationship between banking service quality and customer loyalty?

\section{Literature Review \& Development Hypotheses}

Kranias and Bourlessa (2013) found that adequate proximity to a bank significantly affects customer loyalty. Consequently, Greek banks have redesigned their services to increase customer loyalty. Kheng et al. (2010) evaluated the banking sector in Malaysia. They asserted that banks should improve service quality to promote customer loyalty. Leninkumar (2016) revealed that various dimensions of service quality (i.e. Tangibility, reliability and empathy) significantly affect customer loyalty in the Sri Lankan banks. Likewise, Onditi et al. (2012) found that the quality of service greatly affects customer loyalty, given that the quality of service determines customer loyalty. Liu and Wang (2017) concluded that organizations that work to improve service quality through the influence customer loyalty could enhance their performance effectively. On the basis of the above discussion, this study proposes the following hypothesis:

Hypothesis 1: The quality of banking service positively affects customer loyalty.

Raza et al. (2020) and Hammoud et al. (2018) showed that the quality of banking service in its five dimensions has a large and positive effect on customer satisfaction. Al-Azzam (2015) mentioned that the dimensions of banking services positively affect customer satisfaction in Arab Banks. Nautiyal (2014) found that the dimensions of banking service quality affect customer satisfaction in Delhi. Mohammad and Alhamadani (2011) determined whether service quality is an important precedent for customer satisfaction in the Jordanian commercial banking sector. They concluded that the dimensions of service quality have a great effect on customer satisfaction. Recently, Vetrivel et al. (2020) extended the literature to the dimensions of Internet banking services. They revealed that these dimensions positively affect customer satisfaction. On the basis of the above discussion, this study proposes the following hypothesis:

Hypothesis 2: The quality of banking service positively affects customer satisfaction.

Prior studies (e.g. Mohsan et al., 2011; Arokiasamy, 2013) concluded that customer satisfaction has positive and negative relations to customer loyalty and intention to switch. Chiguvi and Guruwo (2017) found a positive relationship between customer satisfaction and customer loyalty. Leninkumar (2017) also found significant positive relationships between customer confidence and loyalty, customer satisfaction and loyalty and customer satisfaction and trust. Moreover, customer satisfaction significantly affects customer loyalty. On the basis of the above discussion, this study proposes the following hypothesis:

Hypothesis 3: Customer satisfaction positively affects customer loyalty.

Fida et al. (2020) showed that the quality of banking service and customer satisfaction and loyalty are highly correlated. The respondents, on average, agreed with the dimensions of the banking service in Oman. Siddiqi (2011) concluded that all features of the quality of banking service have a positive correlation with customer satisfaction. In turn, customer satisfaction positively influences customer loyalty in the banking sector in Bangladesh. Khatoon et al. (2020) found that the quality of banking service dimensions has a significant and positive impact on customers' purchasing intentions. Customer satisfaction (as the mediating variable) has a partial effect on the relationship between the independent and dependent variables. Khan and Fasih (2014) explored the relationship between banking service quality and customer satisfaction and loyalty. Using all of the former's dimensions, they found significant and positive correlations. On the basis of the above discussion, this study proposes the following hypothesis:

Hypothesis 4: Customer satisfaction mediates the relationship between the quality of banking service and customer loyalty.

\subsection{Study Contribution}

This study is a continuation of previous studies related to the issue of the quality of banking services. It focuses on continuously enhancing the quality of banking services. It analyses and evaluates customer behaviour to help banks meet their various needs to achieve their loyalty to the service. This study is characterized by the following features:

Environment and sector: This research applies to branches of Jordanian commercial banks in Tafila Governorate. Its economic activity is diverse in funding sources, foreign investments, competitive small and medium enterprises and many natural resources. This situation also indicates the diversity of clients in this governorate. 
This study is one of the first few studies from the perspective of the researcher which determines whether customer satisfaction mediates the relationship between banking service quality and customer loyalty. , especially in the middle-east environment.

\section{Research Design}

\subsection{Research Model}

On the basis of related studies, the researcher developed the model shown in Figure (1).

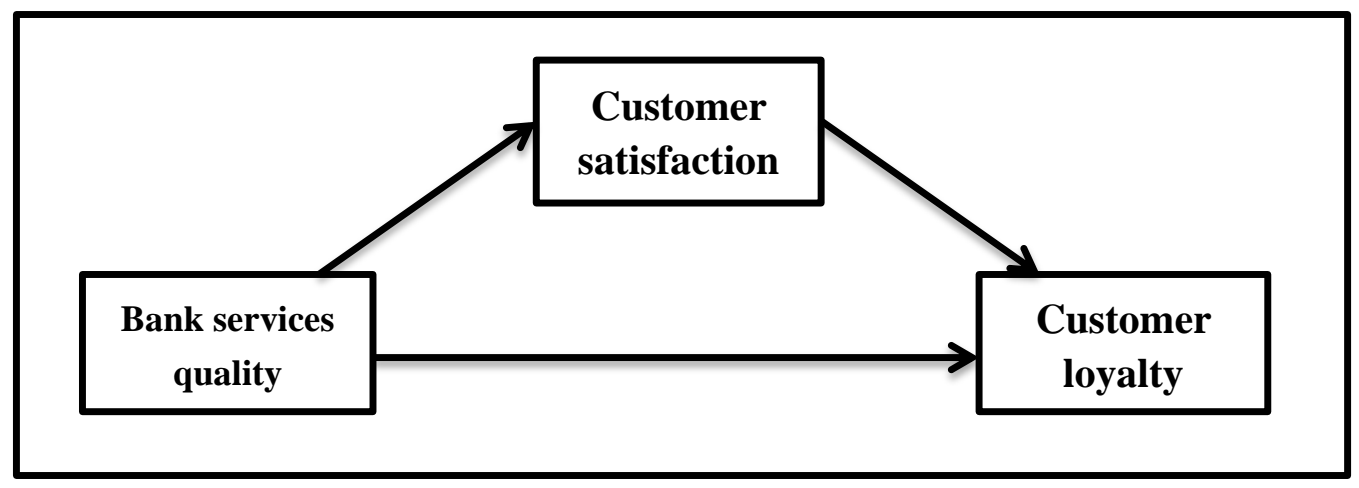

Figure 1. The research model

\subsection{Population and Study Sample}

The study population consisted of all customers in the Jordanian commercial banking sector, including 13 banks. The study community is difficult to restrict, given the expansion of the Jordanian commercial banking sector and an increase in customers. Thus, this study only considered clients in Tafila Governorate. The study sample only included Jordan Ahli Bank, Arab Bank, Housing Bank and Cairo Amman Bank.

\subsection{Data Collection}

The researcher developed a study tool (questionnaire) to obtain data from the respondents. The study tool comprises four sections. The first section explains the demographic data, and the second section discusses the independent variable (i.e. Quality of banking service). The discussion follows prior studies (e.g. Raza et al., 2020; Fida et al., 2020; Siddiqi, 2011; Lomendra et al., 2019; Panichpathom, 2016). The third section explains the mediating variable (e.g. Customer satisfaction) following existing research (e.g. Hammoud et al., 2018; Siddiqi, 2011; Awuor, 2009). The fourth section covers the dependent variable and follows the literature (Mohsan et al., 2011; Leninkumar, 2017). The study tool uses a Likert-type scale ranging between strongly agree and strongly disagree.

On this basis, the researcher selected a convenience sample and distributed 300 questionnaires. Five questionnaires were excluded from the 290 retrieved questionnaires. A total of 285 questionnaires was considered suitable for analysis, accounting for $95 \%$ of the total distributed questionnaires. Table 1 presents the demographic characteristics of the study sample.

Table 1. Demographic characteristics of the study sample

\begin{tabular}{cccc}
\hline Variable & Category & Frequency & Percentage \\
\hline Gender & Male & 177 & 62.1 \\
& Femal & 108 & 37.9 \\
& Total & 285 & $\% 100$ \\
Age & Less than 21 year & 30 & 10.5 \\
& $21-30$ years & 95 & 33.3 \\
& $31-40$ years & 80 & 28.1 \\
& $41-50$ years & 44 & 15.4 \\
& More than 50 years & 36 & 12.6 \\
Educational & Total & 285 & 0100 \\
qualification & Less than secondary & 33 & 11.6 \\
& Diploma & 84 & 29.5 \\
& Bachelor & 114 & 40 \\
\hline
\end{tabular}




\begin{tabular}{cccc}
\hline & Ph.D & 7 & 2.5 \\
Dealing & Total & 285 & $\% 100$ \\
& Less than one yeare & 37 & 13 \\
& $1-5$ years & 128 & 44.9 \\
& $1-10$ years & 64 & 22.5 \\
& More than 10 years & 56 & 19.6 \\
\hline
\end{tabular}

Sources: Smart PLS Output

\subsection{Validity and Reliability}

After developing the questionnaire, the researcher presented it to a group of seven arbitrators with experience and competence in financial and banking sciences and business administration. The necessary adjustments were made to obtain the final version of the questionnaire. On this basis, the study tool (the questionnaire) could achieve the research aim.

The researcher used Cronbach's alpha coefficient to identify the extent of internal consistency between the paragraphs of the questionnaire. The scale test result is statistically acceptable if the Cronbach's alpha value is greater than the threshold of 0.70 (Hair et al., 2010). The closer the Cronbach's alpha to 1, the higher the degree of internal consistency (Sekaran \& Bougie, 2009).

The Cronbach's alpha values of the study variables ranged from 0.808 to 0.915 ), as shown in Table 2 . All of them were greater than 0.70 and considered acceptable for scientific research, indicating internal consistency and stability. Thus, the questionnaire was valid for analysis.

To verify the internal consistency, the researcher tested the composite reliability. With a value ranging between 0 and 1 , its value is considered acceptable if it is greater than 0.70 . In this study, all the independent variables were acceptable, as shown in Table 2. The average variance extracted (AVE) value is considered acceptable when it exceeds 0.50 . In this study, the AVE was within acceptable limits.

Table 2 indicates that all factor loadings reach more than 0.70 and are within the acceptable limits of this test, except for Paragraph No. 4 within the (tangibles) axis and Paragraph No. 29 within the (customer loyalty) axis. Hence, these paragraphs were dropped in the second-level analysis. Moreover, multicollinearity was not a problem amongst the independent study variables. All tolerance values were greater than 0.2, and all VIF values were less than 5 and within the permissible limits.

Table 2. Factor loadings. Validity, and reliability of the Questionnaire

\begin{tabular}{|c|c|c|c|c|c|c|c|}
\hline Variables & Questions & Factor & $\begin{array}{c}\text { Cronbach's } \\
\text { Alpha }\end{array}$ & $\begin{array}{l}\text { Composite } \\
\text { Reliability }\end{array}$ & $\begin{array}{l}\text { Average Variance } \\
\text { Extracted }\end{array}$ & Tolerance & VIF \\
\hline \multirow[t]{5}{*}{ Tangibles } & Q1 & 0.763 & 0.818 & 0.873 & 0.580 & .626 & 1.598 \\
\hline & Q2 & 0.796 & & & & & \\
\hline & Q3 & 0.776 & & & & & \\
\hline & Q4 & 0.685 & & & & & \\
\hline & Q5 & 0.792 & & & & & \\
\hline \multirow[t]{5}{*}{ Reliability } & Q6 & 0.805 & 0.915 & 0.937 & 0.749 & .473 & 2.115 \\
\hline & Q7 & 0.855 & & & & & \\
\hline & Q8 & 0.933 & & & & & \\
\hline & Q9 & 0.798 & & & & & \\
\hline & Q10 & 0.926 & & & & & \\
\hline \multirow[t]{4}{*}{ Responsiveness } & Q11 & 0.792 & 0.813 & 0.877 & 0.640 & .326 & 3.068 \\
\hline & Q12 & 0.795 & & & & & \\
\hline & Q13 & 0.824 & & & & & \\
\hline & Q14 & 0.789 & & & & & \\
\hline Empathy & Q15 & 0.907 & 0.896 & 0.924 & 0.710 & .296 & 3.377 \\
\hline
\end{tabular}




\begin{tabular}{|c|c|c|c|c|c|c|c|}
\hline & Q16 & 0.823 & & & & & \\
\hline & Q17 & 0.915 & & & & & \\
\hline & Q18 & 0.771 & & & & & \\
\hline & Q19 & 0.785 & & & & & \\
\hline \multirow[t]{4}{*}{ Safety } & Q20 & 0.819 & 0.808 & 0.874 & 0.635 & .301 & 3.322 \\
\hline & Q21 & 0.734 & & & & & \\
\hline & Q22 & 0.808 & & & & & \\
\hline & Q23 & 0.823 & & & & & \\
\hline \multirow{5}{*}{$\begin{array}{l}\text { Customer } \\
\text { satisfaction }\end{array}$} & Q24 & 0.784 & 0.845 & 0.890 & 0.618 & .242 & 4.133 \\
\hline & Q25 & 0.795 & & & & & \\
\hline & Q26 & 0.791 & & & & & \\
\hline & Q27 & 0.853 & & & & & \\
\hline & Q28 & 0.763 & & & & & \\
\hline \multirow[t]{5}{*}{ Customer Loyalty } & Q29 & 0.679 & 0.896 & 0.925 & 0.715 & .303 & 3.304 \\
\hline & Q30 & 0.914 & & & & & \\
\hline & Q31 & 0.872 & & & & & \\
\hline & Q32 & 0.805 & & & & & \\
\hline & Q33 & 0.934 & & & & & \\
\hline
\end{tabular}

Sources: Smart PLS Output

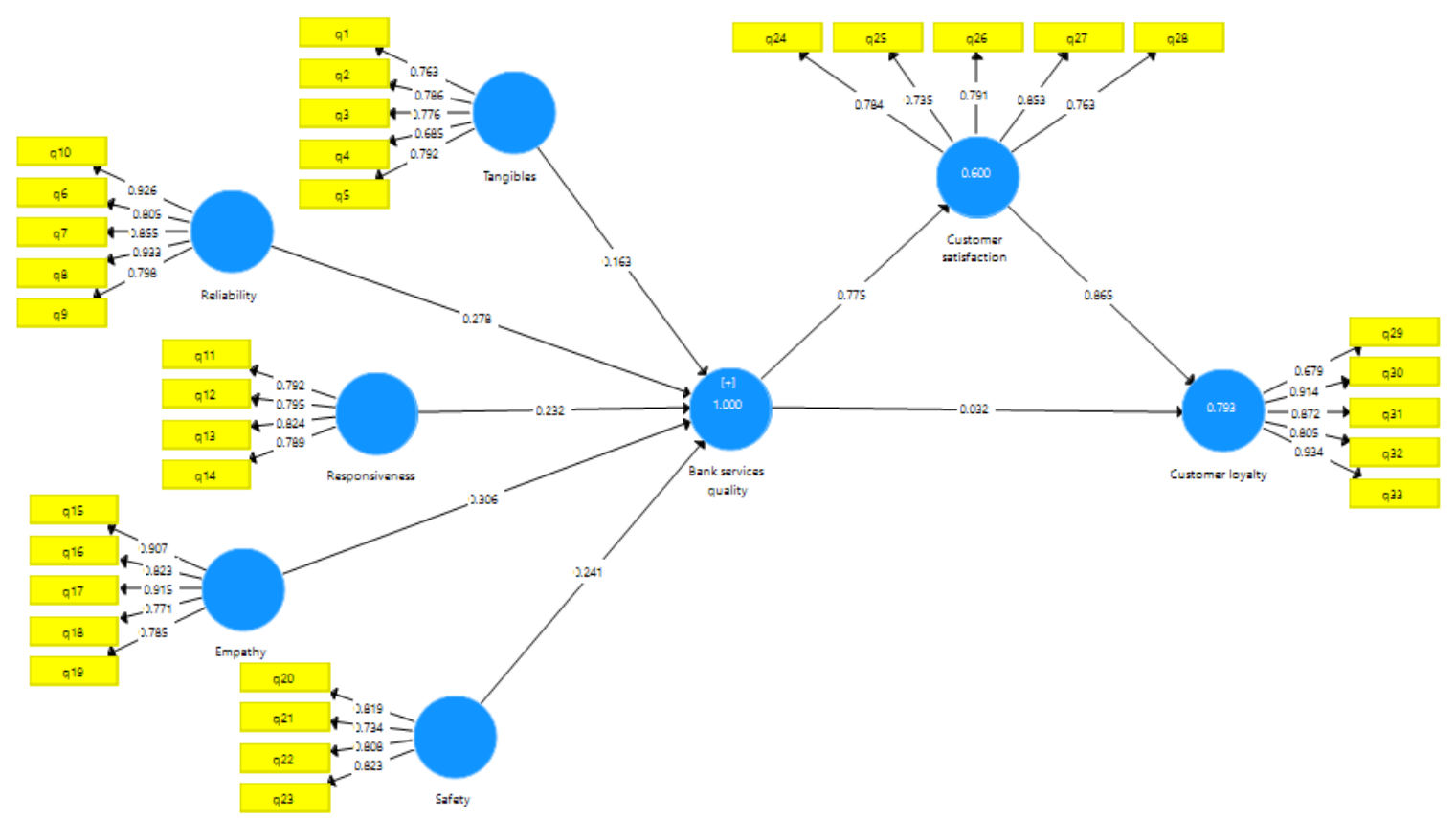

Figure 2. the model of standardized loading and path coefficient for the trimmed model

\section{Discussion}

\subsection{Mean and Standard Deviations}

Table 3 shows the arithmetic mean, standard deviation and the relative importance of all study variables. The arithmetic mean and the relative importance of all the variables reach the average level. Thus, the quality of banking service in all its dimensions, customer satisfaction and customer loyalty are moderate, considering the study sample under examination and analysis. 
Table 3. Mean, standard deviations, and level

\begin{tabular}{|c|c|c|c|c|}
\hline Variables & Questions & Mean & S.D & Level \\
\hline \multirow[t]{6}{*}{ Tangibles } & Q1 & 2.04 & .846 & low \\
\hline & Q2 & 2.56 & 1.004 & moderate \\
\hline & Q3 & 2.33 & .857 & low \\
\hline & Q4 & 2.64 & .967 & moderate \\
\hline & Q5 & 2.67 & .943 & moderate \\
\hline & General arithmetic mean & 2.44 & & moderate \\
\hline \multirow[t]{6}{*}{ Reliability } & Q6 & 2.47 & .882 & moderate \\
\hline & Q7 & 2.35 & .862 & moderate \\
\hline & Q8 & 2.30 & .726 & low \\
\hline & Q9 & 2.47 & .890 & moderate \\
\hline & Q10 & 3.15 & 1.034 & moderate \\
\hline & General arithmetic mean & 2.54 & & moderate \\
\hline \multirow[t]{5}{*}{ Responsiveness } & Q11 & 2.45 & .848 & moderate \\
\hline & Q12 & 2.43 & .915 & moderate \\
\hline & Q13 & 2.52 & .940 & moderate \\
\hline & Q14 & 2.39 & .926 & moderate \\
\hline & General arithmetic mean & 2.44 & & moderate \\
\hline \multirow[t]{6}{*}{ Empathy } & $\mathrm{Q} 15$ & 2.30 & .813 & low \\
\hline & Q16 & 2.48 & .918 & moderate \\
\hline & Q17 & 2.42 & .941 & moderate \\
\hline & Q18 & 2.80 & 1.038 & moderate \\
\hline & Q19 & 2.66 & 1.017 & moderate \\
\hline & General arithmetic mean & 2.53 & & moderate \\
\hline \multirow[t]{5}{*}{ Safety } & $\mathrm{Q} 20$ & 2.64 & .974 & moderate \\
\hline & Q21 & 3.01 & .984 & moderate \\
\hline & Q22 & 2.33 & .959 & low \\
\hline & Q23 & 2.40 & .987 & moderate \\
\hline & General arithmetic mean & 2.59 & & moderate \\
\hline \multirow[t]{6}{*}{ Customer satisfaction } & $\mathrm{Q} 24$ & 2.52 & .898 & moderate \\
\hline & Q25 & 2.73 & .960 & moderate \\
\hline & Q26 & 2.46 & .898 & moderate \\
\hline & Q27 & 2.50 & .937 & moderate \\
\hline & Q28 & 2.40 & .801 & moderate \\
\hline & General arithmetic mean & 2.52 & & moderate \\
\hline \multirow[t]{6}{*}{ Customer Loyalty } & Q29 & 2.56 & .865 & moderate \\
\hline & Q30 & 2.53 & .850 & moderate \\
\hline & Q31 & 3.04 & 1.122 & moderate \\
\hline & Q32 & 2.52 & .906 & moderate \\
\hline & Q33 & 2.44 & .997 & moderate \\
\hline & General arithmetic mean & 2.61 & & moderate \\
\hline
\end{tabular}

Means description (1 - 2.33 low, 2.34 - 3.67 moderate, $3.68-5$ high)

Sources: Smart PLS Output

\subsection{Test Hypotheses}

\section{Analysis of Hypothesis 1 Test Results}

Table 4 shows the test results of Hypothesis 1 . The effect of the quality of banking service has a positive explanatory power of $43.1 \%$ of customer loyalty. This effect is statistically significant at the 0.05 level and supported by the t-test result of 19.403 which is greater than its tabulated value. Therefore, Hypothesis 1 is accepted. The quality of banking service in all its dimensions has a positive effect on customer loyalty.

Moreover, all dimensions of banking service quality are statistically significant at a level of less than 0.05 . The dimension of empathy $(\beta=0.207)$ has a greater effect on customer loyalty than reliability $(\beta=0.194)$ and responsiveness $(\beta=0.155)$. 
Table 4. First Hypotheses Testing Result

\begin{tabular}{|c|c|c|c|c|c|c|}
\hline Dependent & Independent Variables & & & & & \\
\hline \multirow{10}{*}{$\begin{array}{c}\text { Customer } \\
\text { Loyalty }\end{array}$} & & $\boldsymbol{\beta}$ & SD & T-test & Sig & Result \\
\hline & Bank services quality & 0.657 & 0.034 & 19.403 & 0.000 & Accepted \\
\hline & \multicolumn{6}{|c|}{$\underline{\text { Dimensions Effect }}$} \\
\hline & Tangibles & 0.102 & 0.011 & 8.901 & 0.000 & Accepted \\
\hline & Reliability & 0.194 & 0.012 & 15.704 & 0.000 & Accepted \\
\hline & Responsiveness & 0.155 & 0.012 & 13.367 & 0.000 & Accepted \\
\hline & Empathy & 0.207 & 0.014 & 14.465 & 0.000 & Accepted \\
\hline & Safety & 0.149 & 0.012 & 12.873 & 0.000 & Accepted \\
\hline & $\mathrm{R}^{2}$ & 0.431 & & & & \\
\hline & $\mathrm{R}^{2}$ Adjusted & 0.429 & & & & \\
\hline
\end{tabular}

\section{Analysis of Hypothesis 2 Test Results}

Table 5 shows the test results of Hypothesis 2 . The value of $R^{2}(0.605)$ indicates that the quality of banking service has a positive explanatory power amounting to $60.5 \%$ of the change in customer satisfaction, and this effect is statistically significant at 0.05 level. This finding is enhanced by the t-test value of 31.776 , which is greater than its tabulated value. Thus, Hypothesis 2 is accepted. The quality of banking service in all its dimensions has a positive effect on customer satisfaction.

The results in Table 5 also indicate that all the dimensions of banking service quality are statistically significant at the 0.05 level. This finding is consistent with those of Hypothesis 1 in the first and second dimensions. The dimension of empathy $(\beta=0.245)$ has the greatest effect, followed by reliability $(\beta=0.231)$ and safety $(\beta=0.181)$.

Table 5. Second Hypotheses Testing Result

\begin{tabular}{|c|c|c|c|c|c|c|}
\hline Dependent & \multicolumn{6}{|l|}{ Independent Variables } \\
\hline \multirow{10}{*}{$\begin{array}{c}\text { Customer } \\
\text { Satisfaction }\end{array}$} & & $\boldsymbol{\beta}$ & SD & T-test & Sig & Result \\
\hline & Bank services quality & 0.778 & 0.024 & 31.776 & 0.000 & Accepted \\
\hline & \multicolumn{6}{|c|}{$\underline{\text { Dimensions Effect }}$} \\
\hline & Tangibles & 0.120 & 0.013 & 9.550 & 0.000 & Accepted \\
\hline & Reliability & 0.231 & 0.012 & 19.601 & 0.000 & Accepted \\
\hline & Responsiveness & 0.177 & 0.009 & 20.723 & 0.000 & Accepted \\
\hline & Empathy & 0.245 & 0.012 & 20.427 & 0.000 & Accepted \\
\hline & Safety & 0.181 & 0.011 & 16.530 & 0.000 & Accepted \\
\hline & $\mathrm{R}^{2}$ & 0.605 & & & & \\
\hline & $\mathrm{R}^{2}$ Adjusted & 0.603 & & & & \\
\hline
\end{tabular}

\section{Analysis of Hypothesis 3 Test Results}

The results in Table 6 refer to the test results of Hypothesis 3. Customer satisfaction has a positive interpretation of customer loyalty $\left(R^{2}=0.605\right)$. This result is confirmed by the t-test value of 72.004 , which is greater than its tabulated value. Thus, Hypothesis 3 is accepted. Customer satisfaction has a positive effect on customer loyalty. 
Table 6. Third Hypotheses Testing Result

\begin{tabular}{c|lcccccc}
\hline $\begin{array}{c}\text { Dependent } \\
\text { Variable }\end{array}$ & \multicolumn{7}{l}{ Independent Variables } \\
\hline Customer & \multicolumn{2}{l}{ S } & S & T-test & Sig & Result \\
Loyalty & Customer Satisfaction & 0.875 & 0.012 & 72.004 & 0.000 & Accepted \\
\hline & $\mathrm{R}^{2}$ & 0.605 & & & & & \\
& $\mathrm{R}^{2}$ Adjusted & 0.604 & & & & & \\
\hline
\end{tabular}

\section{Analysis of Hypothesis 4 Test Results}

The results in Table 7 refer to the test results of Hypothesis 4. It states that customer satisfaction mediates the relationship between banking service quality and customer loyalty. To test the intermediate variable hypothesis, the researcher relied on the method proposed by a prior study (Preacher \& Hayes, 2008), which is based on the following two tests:

\section{1- Bootstrap the indirect effect (Total effect)}

The effect of the independent variable on the dependent variable is tested (the total effect). The first condition indicates a statistically significant relationship between the independent and dependent variables, even with the mediating variable. In Table 7, the effect of the quality of banking service has a positive explanatory power amounting to $79.3 \%$ of the change in customer loyalty in the presence of customer satisfaction. Customer satisfaction as an intermediary variable has increased the above direct effect compared with Hypothesis 1 (43.1\%) in Table 4. The t-test value is 16.363 , which is greater than its tabulated value.

Table 7. Forth Hypotheses Testing Result

\begin{tabular}{|c|c|c|c|c|c|c|c|c|}
\hline $\begin{array}{c}\begin{array}{c}\text { Independen } \\
\text { Variable }\end{array} \\
\end{array}$ & & $\begin{array}{c}\text { Mediator } \\
\text { Variable } \\
\end{array}$ & $\begin{array}{c}\text { Dependent } \\
\text { Variable }\end{array}$ & $\bar{\beta}$ & SD & T-test & Sig & Result \\
\hline BSQ & ------> & $\mathrm{CS}$ & $-\cdots>C L$ & 0.670 & 0.041 & 16.363 & 0.000 & Accepted \\
\hline $\mathrm{R}^{2}$ & & 0.793 & & & & & & \\
\hline $\mathrm{R}^{2}$ Adjusted & & 0.792 & & & & & & \\
\hline
\end{tabular}

Whereas: BSQ: Bank services quality. CS: Customer satisfaction. CL: Customer loyalty

\section{2- Bootstrap confidence interval (Lower and upper levels)}

The second condition verifies the effect of the mediating variable (Preacher \& Hayes, 2008). The upper and lower limits were bootstrapped at a confidence level of $95 \%$. In Table 8, the lower and upper limits of the confidence interval are 0.600 and 0.791 .

Zero does not interrupt these two values. Thus, customer satisfaction mediates the relationship between banking service quality and customer loyalty, supporting Hypothesis 4.

Table 8. Template for Mediation Calcuation

\begin{tabular}{|c|c|c|c|c|c|c|c|c|}
\hline & \multirow[b]{2}{*}{ Path a } & \multirow[b]{2}{*}{ Path b } & \multirow[b]{2}{*}{$\begin{array}{c}\text { Indirect } \\
\text { Effect }\end{array}$} & \multicolumn{5}{|c|}{ Bootstrapped Confidence Interval } \\
\hline \multirow[b]{2}{*}{ H4 } & & & & $\mathbf{S E}$ & t-value & $95 \% \mathrm{LL}$ & $95 \% \mathrm{UL}$ & Decision \\
\hline & 0.778 & 0.875 & 0.681 & 0.041 & 16.604 & 0.600 & 0.761 & Mediation \\
\hline
\end{tabular}




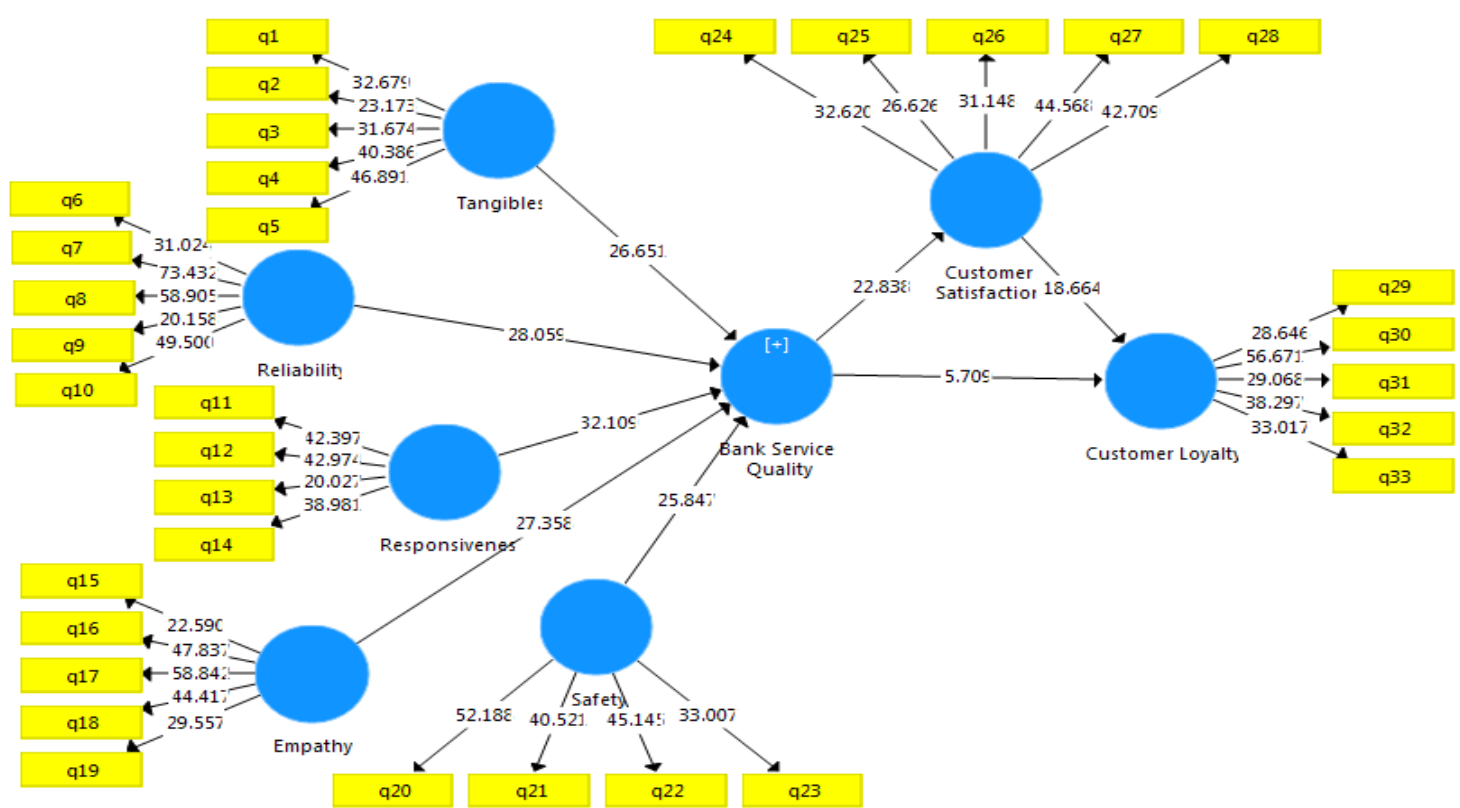

Figure 3. the model of standardized loading and path coefficient for the trimmed model, after deleting questions $(4 \& 29)$

\section{Conclusion}

The arithmetic averages of all the variables reach the average level, indicating that customer satisfaction and loyalty are generally average for the quality of banking services provided to the sample under examination and analysis.

The researcher also validated the SERVQUAL model in the five dimensions investigated in this study using SmartPLS. The dimensions with the greatest effects on customer loyalty are empathy, reliability and responsiveness. The evaluation of customer satisfaction shows empathy as the best dimension, followed by reliability and safety. The weakest dimension is the tangibility dimension.

The results of the SmartPLS test support Hypothesis 1 . The quality of banking service in all its dimensions has a positive effect on customer loyalty. This finding agrees with prior studies (Kheng et al., 2010; Leninkumar, 2010; Liu \& Wang, 2017). Thus, the quality of banking services is a critical determinant of customer loyalty. It should stay consistent with customer behaviour and perception management, which is positively reflected in the banks' market share.

The analysis results support Hypothesis 2. The quality of banking service in all its dimensions has a positive effect on customer satisfaction. This finding is consistent with prior studies (Raza et al., 2020; Hammoud et al., 2018; Al-Azzam, 2015; Nautiyal, 2014; Mohammad \& Alhamadani, 2011). Thus, banks should improve all dimensions of their service quality. In turn, they can enhance the satisfaction of existing customers and attract more customers in the future.

The test results support Hypothesis 3. Customer satisfaction has a positive effect on customer loyalty. This finding is consistent with prior studies (Leninkuman, 2017; Arokiasamy, 2013; Mohsan et al., 2011; Chiguvi \& Guruwo, 2017). Thus, if customers are satisfied with the provided banking services, they will stay loyal. Satisfaction precedes loyalty; that is, the greater the customer satisfaction, the greater their loyalty to the bank.

Finally, customer satisfaction mediates the relationship between the quality of banking service and customer loyalty. This finding is partly consistent with prior studies (Fida et al., 2020; Siddiqi, 2011; Khan \& Fasih, 2014). Thus, mutual relationships exist between the quality of banking service and customer loyalty through customer satisfaction as a mediating variable. These relationships enhance and develop the options offered in banking services, which lead to advantages in the competitive banking market.

\section{Recommendations}

On the basis of the above results, the Jordanian commercial banking sector should continuously develop and improve the quality of its banking services, with a focus on the tangible dimension. 
Banks should influence customer satisfaction to achieve their loyalty whilst paying attention to their needs.

Banks should invest in factors that may positively affect customer satisfaction and loyalty, such as reducing the processing time, adding more parking spaces and handling complaints quickly. Bank employees should show sincere concern to clients' needs to provide effective services.

Finally, banks should consider increasing their branches in the governorate of Tafila to provide more services in line with the wishes and aspirations of customers.

\section{Limitations and Future Research Directions}

This study was limited to Tafila governorate. Hence, the results should not be generalized easily to other contexts. Future research should focus on larger cities with a higher number of clients.

Future works should also cover other variables, such as confidence, bank location and confidentiality, and customers of different demographic and cultural variables.

\section{References}

Ajmal, H., Khan, R., \& Fatima, M. (2018). Impact of service quality on customer satisfaction in banking industry of Pakistan: A case study of Karachi. Journal of Social and Administrative Sciences, 5(3), 219-238.

Al Karim, R., \& Chowdhury, T. (2014). Customer satisfaction on service quality in private commercial banking sector in Bangladesh. British Journal of Marketing Studies, 2(2), 1-11.

Al-Azzam, A. (2015). The Impact of Service Quality Dimensions on Customer Satisfaction: A Field Study of Arab Bank in Irbid City, Jordan. European Journal of Business and Management, 7(15), 54-53

Alic, A., Agic, E., \& Cinjarevic, M. (2017). The importance of store image and retail service quality in private brand image-building. Entrepreneurial Business and Economics Review, 5(1), 27-42. https://doi.org/10.15678/EBER.2017.050102

Angur, M., Nataraajan, R., \& Jahera, J. (1999). Service quality in the banking industry: An assessment in a developing economy. International Journal of Bank Marketing, 17(3), 116-125. https://doi.org/10.1108/02652329910269211

Arokiasamy, A. (2013). The impact of customer satisfaction on customer loyalty and intentions to Switch in the banking sector in Malysia. The Journal of Commerce, 5(1), 14-21.

Association of banks in Jordan, Annual report. (2019). Retrieved from https://www.abj.org.jo/

Awuor, B. (2009). Service quality and customer satisfaction in the banking sector in Kenya. Unpublished masters thesis, University of Nairobi.

Bitner, M., \& Hubbert, A. (1994). Encounter satisfaction versus over satisfaction versus quality: The Customer's Voice. New Directions in Theory and Practice, 79-84.

Brown, T., Churchill, G., \& Peter, J. (1993). Improving the measurement of service quality. Journal of Retailing, 69(1), 127-139. https://doi.org/10.1016/S0022-4359(05)80006-5

Carman, J. (1990). Consumer perceptions of service quality: An assessment of the SERVQUAL dimensions. Journal of Retailing, 66(1), 35-55.

Central Bank of Jordan, Annual report (2019). Retrieved from https://www.cbj.gov.jo/

Chiguvi, D., \& Guruwo, P. (2017). Impact of Customer Satisfaction on Customer Loyalty in the Banking Sector. International Journal of Scientific Engineering and Research, 5(2), 55-63.

Edvardsson, B., Thomasson, B., \& Ovretveit, J. (1994). Quality of service: Making it really work (1st ed.). Berkshire: Mc Graw-Hill.

Eltahir, O., \& Abdallah, N. (2019). The impact of quality of banking service on the satisfaction of customers of commercial banks in the province of Darb - Saudi Arabia. Arab Journal for Scientific Publishing, 14, 74-98.

Fida, B., Ahmed, U., Al-Balushi, Y., \& Singh, D. (2020). Impact of Service Quality on Customer Loyalty and Customer Satisfaction in Islamic Banks in the Sultanate of Oman. Journals.sagepub.com/home/sgo, SAGE Open, 1-10. https://doi.org/10.1177/2158244020919517

Flint, D., Blocker, C., \& Boutin, P. (2011). Customer value anticipation, customer satisfaction and loyalty: An empirical examination. Industrial Marketing Management, 40(2), 219-230.

https://doi.org/10.1016/j.indmarman.2010.06.034 
Fragoso, J., \& Espinoza, I. (2017). Assessment of banking service quality perception using the SERVPERF model. Contaduría y Administración, 62, 1294-1316. https://doi.org/10.1016/j.cya.2017.06.011

Hair, J., Black, W., Babin, B., \& Anderson, R. (2010). Multivariate Data Analysis: A global Perspective (7th ed.). Pearson Education, Inc., Saddle River, New Jersey.

Hammoud, J., Bizri, R., \& El Baba, I. (2018). The Impact of E-Banking Service Quality on Customer Satisfaction: Evidence From the Lebanese Banking Sector. Journals.sagepub.com/home/sgo, SAGE Open, 1-12. https://doi.org/10.1177/2158244018790633

Kadir, H., Rahmani, N., \& Masinaei, R. (2011). Impacts of service quality on customer satisfaction: Study of Online banking and ATM services in Malaysia. International Journal of Trade, Economics and Finance, 12(1), 1-9. https://doi.org/10.7763/IJTEF.2011.V2.71

Khan, M., \& Fasih, M. (2014). Impact of Service Quality on Customer Satisfaction and Customer Loyalty: Evidence from Banking Sector, Pakistan. Journal of Commerce and Social Sciences, 8(2), 331-354.

Khatoon, S., Zhengliang, X., \& Hussain, H. (2020). The Mediating Effect of Customer Satisfaction on the Relationship Between Electronic Banking Service Quality and Customer Purchase Intention: Evidence From the Qatar Banking Sector. journals.sagepub.com/home/sgo, SAGE Open, 1-12. https://doi.org/10.1177/2158244020935887.

Kheng, L., Mahamad, O., Ramayah, T., \& Mosahab, R. (2010). The Impact of Service Quality on Customer Loyalty: A Study of Banks in Penang, Malaysia. International Journal of Marketing Studies, 2(2), 57-66. https://doi.org/10.5539/ijms.v2n2p57

Kotler, P. (2003). Marketing insights from A to Z (1st ed.). New jersey, John Wiley \& Sons, No (50).

Kotler, P., \& Keller, K. (2012). Marketing management (14th ed.). Pearson - Hall No (65).

Kotler, P., \& Keller, K. L. (2006). Marketing Management. New Delhi, India: Prentice-Hall.

Kranias, A., \& Bourlessa, M. (2013). Investigating the relationship between service quality and loyalty in Greek banking sector. International Conference on Applied Economics, 5, 453-458. https://doi.org/10.1016/S2212-5671(13)00053-1

Kumar, M., Kee, F., \& Charle, V. (2010). Comparative evaluation of critical factors in delivering service quality of banks: An application of dominance analysis in modified SERVQUAL model. International Journal of Quality \& Reliability Management, 27(3), 351-377. https://doi.org/10.1108/02656711011023320

Lau, M., Cheung, R., Lam, A., \& Chu, Y. (2013). Measuring service quality in the banking industry: A Hong Kong Based Study. Contemporary Management Research, 9(30), 263-282. https://doi.org/10.7903/cmr.11060

Leninkumar, V. (2016). The Effect of Service Quality on Customer Loyalty. European Journal of Business and Management, 8(33), 44-49.

Leninkumar, V. (2017). The Relationship between Customer Satisfaction and Customer Trust on Customer Loyalty. International Journal of Academic Research in Business and Social Sciences, 7(4), 450-465. https://doi.org/10.6007/IJARBSS/v7-i4/2821

Liu, C., \& Wang, T. (2017). A study on the effect of service quality on customer loyalty and corporate performance in financial industry. Problems and Perspectives in Management, 15(2), 355-363. https://doi.org/10.21511/ppm.15(2-2).2017.05

Liu, Y., Li, Y., Tao, L., \& Wang, Y. (2008). Relationship stability, trust and relational risk in marketing channels: Evidence from China. Industrial Marketing Management, 37(4), 432-446. https://doi.org/10.1016/j.indmarman.2007.04.001

Lomendra, V., Sharmila, P., Roubina, J., Ganess, D., \& Zabeen, S. (2019). Assessing the impact of service quality dimensions on customer satisfaction in commercial bank of Mauritius. Studies in Business and Economics, 14(1), 259-270. https://doi.org/10.2478/sbe-2019-0020

Mohammad, A., \& Alhamadani, S. (2011). Service Quality Perspectives and Customer Satisfaction in Commercial Banks Working in Jordan. Middle Eastern Finance and Economics, 14, 60-72.

Mohsan, F., Nawaz, M., Khan, M., Shaukat, Z., \& Aslam, N. (2011). Impact of Customer Satisfaction on Customer Loyalty and Intentions to Switch: Evidence from Banking Sector of Pakistan. International Journal of Business and Social Science, 2(16), 263-270. 
Naeem, H., Akram, A., \& Saif, I. (2009). Service Quality And Its Impact On Customer Satisfaction: An Empirical Evidence From The Pakistani Banking Sector. International Business \& Economics Research Journal, 8(12), 99-104. https://doi.org/10.19030/iber.v8i12.3201

Nautiyal, G. (2014). Impact of service quality on customer satisfaction in the retail banking sector. Global Journal of Commerce \& Management Perspective, 3(3), 77-80.

Onditi, A., Oginda, M., Ochieng, I., \& Oso, W. (2012). Implications of Service Quality on Customer Loyalty in the Banking Sector. A Survey of Banks in Homabay County, Kenya. International Journal of Business and Social Science, 3(21), 223-233.

Panichpathom, S. (2016). Building Customers re-patronage intention through service quality of community mall in Bangkok. Entrepreneurial Business and Economics Review, 4(2), 9-25. https://doi.org/10.15678/EBER.2016.040202

Parasuraman, A., Zeithamal, V., \& Berry, L. (1988). SERVQUAL: A multiple-item scale for measuring consumer perceptions of service quality. Journal of Retailing, 64(1), 12-40.

Phan, C., \& Nham, P. (2015). Impact of service quality on customer satisfaction of automated teller machine service: case study of a private commercial joint stock bank in Vietnam. Business: Theory and Practice, 16(3), 280-289. https://doi.org/10.3846/btp.2015.510

Preacher, K., \& Hayes, A. (2008). Asymptotic and resampling strategies for assessing and comparing indirect effects in multiple mediator models. Behavior Research Methods, 40(3), 879-891. https://doi.org/10.3758/BRM.40.3.879

Raza, H., Burney, A., \& Ahsanullah. (2020). Impacts of service quality on customer satisfaction: A comparative study on banking sector of Pakistan through weighted SERVPERF Model. International Transaction Journal of Engineering, Management, \& Applied Sciences \& Technologies, 11(2), 1-15.

Sakhaei, S., Afshari, A., \& Esmaili, E. (2014). The Impact of Service Quality on Customer Satisfaction in Internet Banking. Journal of Mathmatics and Computer Science, 9, 33-40. https://doi.org/10.22436/jmcs.09.01.04

Sekaran, U., \& Bougie, R. (2009). Research methods for business: A skill building approach (5th ed.). New York, NY: John Wiley \& sons INC.

Siddiqi, K. (2011). Interrelations between Service Quality Attributes, Customer Satisfaction and Customer Loyalty in the Retail Banking Sector in Bangladesh. International Journal of Business and Management, 6(3), 12-36. https://doi.org/10.5539/ijbm.v6n3p12

Vetrivel, S., Rajini, J., \& Krishnamoorthy, V. (2020). Influence of internet banking service quality on customer satisfaction- An Indian experience. Journal of Critical Reviews, 7(2), 546-551. https://doi.org/10.31838/jcr.07.02.102

Zeithaml, V., Parasuraman, A., \& Malhotra, A. (2002). Service Quality Delivery Through Web Sites: A Critical Review of Extant Knowledge. Journal of the Academy of Marketing Science, 30(1), 362-375.

https://doi.org/10.1177/009207002236911

\section{Copyrights}

Copyright for this article is retained by the author(s), with first publication rights granted to the journal.

This is an open-access article distributed under the terms and conditions of the Creative Commons Attribution license (http://creativecommons.org/licenses/by/4.0/). 